\title{
Literacy in Storytelling Model Teacher with Learning in Primary Circuit City Bandung
}

\author{
Cherawati, Bachrudin Mustafa, Isah Cahyani \\ Universitas Pendidikan Indonesia, Bandung, Indonesia \\ cherawati@upi.edu
}

\begin{abstract}
The research was carried out based on the development of literacy in elementary school movement. Entering the 21 st century, learning literacy has the main objective to provide an opportunity or an opportunity for students to develop themself as a competent communicator in the context of multiliteracy, multicultural and multimedia through its multi-intelligence empowerment. Learning literacy in the elementary curriculum subjects entered in the Indonesian language and literature. In line with this fact, the initial effort should be done to realize the literacy learning is to improve the quality of teachers. Through improving the quality of teachers, teachers are able to develop the quality of learning they have implemented. Improved quality of learning on improving the quality of graduates. The circuit model of learning is a learning model that maximizes empowering thoughts and feelings with the addition pattern and repetition. This study aims to describe: (1) determine the profile of literacy storytelling teacher in elementary school, (2) determine the design of storytelling teachers with models of circuit learning to cultivate the character of students in elementary schools, (3) determine the structure or system presenting fairy tales that can attract students in elementary schools, (4) evaluate the response of students in literacy storytelling teacher at the elementary school. This study used a qualitative approach with the case study method. This research subject is an elementary school teacher in Bandung. The data source of research is: (1) a written source, (2) oral sources, (3) the documents, and (4) recording. Data collection techniques are observation, interviews, and documentation. The process of data analysis research conducted with a qualitative descriptive technique. The results of the study as follows. (1) primary school teachers who have implemented literacy Bandung storytelling, (2) increasing the effectiveness of teachers using circuit models of learning, and (3) increasing the quality of primary school education in the city of Bandung.
\end{abstract}

Keywords: Literacy teacher storytelling, character education, learning circuit models, elementary school.

\section{Introduction}

In 2016 the Ministry of Education and Culture embed student literacy skills enhancement programs in the School Literacy Movement. Traditionally, literacy is seen as the ability to read and write. However, later developed into the notion of literacy proficiency include reading, writing, speaking, and listening. In this development, literacy includes scientific literacy, mathematics literacy, social science literacy, media literacy, information literacy, financial literacy, literacy cooking, and various types of literacy more. Literacy skills in the field of science is an important skill that must be 
mastered in an increase in world education students to be able to compete in world competitiveness.

Entering the 21 st century, learning literacy ultimate goal is to provide an opportunity or an opportunity for students to develop themself as a competent communicator in the context of multiliteracy, multicultural and multimedia through its multi-intelligence empowerment. The purpose of literacy in the 21 st century includes: 1) Establish the students to become readers, writers, and communicators are strategic. 2) Improving the ability to think and develop the habit of thinking in students. 3) Increase and deepen students' motivation. 4) Develop students' independence as learners who are creative, innovative, productive, and character (The Ontario Ministry of Education, 2006).

The fairy tale is a work of literature that contains the values of life and the value of education. Fairytale offer life story of good and evil symbolized by the behavior and attitudes of the characters. Therefore, the story of readers or listeners may benefit which can be applied in everyday life. Growth character entered in the affective (attitude). In Bloom's taxonomy, the affective aspect consists of five stages, namely acceptance (receiving/attending), response (responding), awards (valuing), organizing (organization), and characterization based on the values (characterization by a value or value complex) (Krathwohl, et al. 1964: 64).

In line with the literacy movement in building a child's character and functions and objectives of the comprehensive education by leaps and bounds, the role of the teacher got a lot of extra dimensions as a teacher as well as a bright career with rewarding high enough. The literacy movement in school will not be possible without qualified teachers. In line with this fact, the initial effort should be done to realize the literacy learning is to improve the quality of teachers. , Some of the specific skills of literacy teachers are classified Block and Mangieri (2009) in the following six aspects: 1) Pera, Responsibility, and Talent is needed. 2) Motivation. 3) Remedial Education. 4) About the Students. 5) Quality Class. 6) Characteristics of the study.

This study uses phenomenological qualitative methods, to understand the stimulation of the teachers to improve the literacy of preschool children and to identify factors that support and the factors that inhibit the stimulation of child literacy in primary school. Extension activities begin with a preliminary case study in advance. The introduction of programs with elementary school teachers in the city of Bandung. As well as applying the learning model Learning Circuit. Circuit model of learning (learning play) developed by Teller (in De Porter, 1999: 180) an education consultant, this model contains three sequential steps. a) The state of calm at the time of learning. b) The mind map and write notes interchanges. c) Add and repeat.

The learning model Circuit Learning used as a researcher and collaborator for this model is one approach model of thinking and problem-based that is able to encourage students to maximize empowering thoughts and feelings with the pattern of addition (adding) and repetition (repetition) that starts from questions and answers about the topic studied, the presentation of a concept map, an explanation of the concept maps, the division into several groups, student worksheets filling accompanied with a concept 
map, a description of procedures for charging, the implementation of group presentations, and reward or praise (Huda, 2013: 311).

\section{Result and Discussion}

\subsection{School Literacy Movement}

In this global era, information literacy is important. Alexandria Declaration in 2005 (as released in www.unesco.org) describes that information literacy is the ability to manage the knowledge and ability to learn continuously. Information literacy is the ability to realize the need for information and when information is needed, identify and locate the necessary information, evaluate information critically, organize and integrate information into existing knowledge, utilize and communicate effectively, legally and ethically.

Literacy is the ability to read and write. In a broad sense, literacy includes the ability to speak, listen, and think as an element in it (Cooper, 1993). Literacy if he has the right knowledge and skills to be used in any activities that require literacy function effectively in society and literacy gained through reading, writing, and arithmetic that allows it to be used for self and community development (Baynham, 1995).

Elementary literacy skills in the lower classes, in articulating communicate empathy to story. While the high-class level is able to present the story effectively and be able to determine the type of writing in the media and its objectives. The creativity of teachers is an important factor in presenting programs and activities of reading, writing, listening, and speaking intelligently so that learners can internalize positive values contained therein. Habituation non-teaching reading for fifteen minutes before the lesson begins, as stipulated in Permendikbud No. 23 on Growth Budi Character needs to be an alternative to foster and initiate movements literacy in schools.

\subsection{Characters and Character Education}

Dewantara (1962) argues that the term "character, character, character" as a determination of the human soul or the unification movement of thought, feeling, and will or volition always energize. This is in line with the opinions Budimansyah (2010) that the character is a basic format of human beings in the form of the virtues contained in one's self and serve as guidelines for behavior.

Zubaedi (2012) states that a character is a reflection of one's personality entirely in the form of mentality, attitudes, and behavior. Character (character) refers to a set of attitudes (attitude), behavioral (behaviors), motivation (motivations), and skills (skills). According to Samani \& Hariyanto (2014) character is interpreted as a way of thinking and behaving that is typical of every individual to live and work together both within the family, community, nation, and state. While Scerenko (in Samani \& Hariyanto, 2014) considers that the attribute or character traits that make up and distinguish personal characteristics, traits ethical and mental complexity of a person, a group or a nation. 
Expert opinions above show the importance of character as it is a basic format, code of conduct, which is not only a reflection of the behavior of individuals but also reflect an identity that reflects a group or nation.

The importance of this character is recognized by one of the main characters of Thomas lickona's character education. Lickona (1991) argues that the character education has three main elements, namely know the good (knowing the good), lovingkindness (desiring the good), and do good (doing the good). This means that someone after knowing and understanding the meaning of goodness he can put it into practice in daily life and is reflected as a personal ethical and courteous in doing.

Wijayani (2013) states that character education is the process of giving guidance for learners to become fully human, the character in the dimensions of the heart, thought, body and taste, and imagination. Character education can be defined with values education, character education, moral education, character education, which aims to provide a good-bad decision, maintaining what is good, and realize the good in everyday life with a vengeance.

Noble \& Aini (2013) true character education is education that not only rely on and hone intellectual intelligence alone but also to build character-based citizens' human values and national values, which is based on Pancasila as the state ideology.

Kesuma (2012) character education in the school setting has a purpose: 1) strengthen and develop the values of life that are important and need to be personality/ownership of a typical student participants as well as the values that are developed; 2) correcting student behavior that is incompatible with the values developed by the school; and 3) establish responsibility for character education together.

\subsection{Fairytale}

Storytelling (storytelling) is the art of storytelling that involves the skill and imagination of the person who tells the story and the listener and able delivering messages and information. Through stories, messages and information are packaged attractively, in packs of characters and background story that would be more easily digested and absorbed children.

According to Elkabumaini and Ruhmana (2016) fairy tale has several benefits for students, namely: a) media inculcate values and ethics; b) introduced a form of emotion; c) strengthen the bond; d) expanding vocabulary; e) to stimulate the imagination. In this regard, fairytale can help parents to develop a child's imagination, and at the same time also shape the character through a message delivered from a fairy tale children.

GLS conducted through each school, one way that is often used is storytelling. Storytelling can build children's character becomes a better person. Various strategies for learning and school activities implemented to enhance the formation of character.

Here are some ways good storytelling and fun that could do the teachers that are implementation: 1) Choose and prepare a place that meets the criteria in terms of hygiene, safety and comfort of students. 2) storytelling with props, storytelling can use tools such as books, drawings, panel boards, puppets, and films. 3) Storytelling without props, these techniques rely on tone of voice, facial expressions, and movements of the 
body. 4) Expressing characters, this way it can be shown through visual expression. 5) Imitating the sound and voice character. 6) Mengidupkan atmosphere by optimizing dialogue story characters, climax, humor, and involve children in storytelling. 7) Choose diction and sentence structure, This is very important to have teachers in which what is delivered to students should be tailored to the age level easily understood the sense of the word. Teachers can start and end the fairytale with beautiful words and with a happy expression.

\subsection{Circuit Model Learning}

According to DePorter et al (2010: 230) understanding of learning is learning the rotate circuit, called learning play because students actually take the information in the same pattern every day. Meanwhile, according to Huda (2013: 311) learning circuit is "one type of cooperative learning model that maximizes empowering thoughts and feelings with the addition pattern (adding) and repetition (repetition)".

Measures include Circuit Learning1) Do the frequently asked questions about any human activity that can destroy nature, 2) Attaching the concept maps have been made about the human activities that damage ecosystems, 3) Explain the concept map that has been affixed. (Attached), 4) Divide students into groups, 5) Explain that each filled out student worksheets and fill part of the concept maps in accordance with their own language, 6) Explain that part of the map concept that they are doing will be presented, 7) Implement a percentage of each group of parts of the map concept that has been earned, 8) provide reinforcement in the form of praise or a reward for a good percentage of the results as well as to encourage that can not praise or reward for trying even harder.

Steps application circuit model of learning in literacy storytelling is:

\begin{tabular}{|c|c|}
\hline \multicolumn{2}{|c|}{ Step 1} \\
\hline \multicolumn{2}{|l|}{ Storytelling } \\
\hline Teacher: & students: \\
\hline $\begin{array}{l}\text { Communicating the contents of a fairy } \\
\text { tale }\end{array}$ & $\begin{array}{l}\text { Listening to the outline of the tale told by the } \\
\text { teacher. }\end{array}$ \\
\hline \multicolumn{2}{|c|}{ Step 2} \\
\hline \multicolumn{2}{|l|}{ DO FAQS. } \\
\hline Teacher: & students: \\
\hline $\begin{array}{l}\text { Teacher tossed the question who were } \\
\text { the fairy tale character who listened }\end{array}$ & Mentions figures in fairy tales of listening. \\
\hline \multicolumn{2}{|c|}{ Step 3} \\
\hline Figure Drawing attaching and character. & \\
\hline
\end{tabular}




\begin{tabular}{|c|c|}
\hline $\begin{array}{l}\text { Teacher: } \\
\text { Teachers encourage students to take } \\
\text { turns sticking images of characters and } \\
\text { character. }\end{array}$ & $\begin{array}{l}\text { students: } \\
\text { Stick it on about the characters and character } \\
\text { images are take turns in accordance with what } \\
\text { is understood from these tales }\end{array}$ \\
\hline \multicolumn{2}{|c|}{ Step 4} \\
\hline \multicolumn{2}{|l|}{ TAKING PICTURES Malalui FAQs } \\
\hline $\begin{array}{l}\text { students: } \\
\text { Asking questions about the picture } \\
\text { pasted on the board. }\end{array}$ & $\begin{array}{l}\text { students: } \\
\text { Answering questions of teachers. }\end{array}$ \\
\hline \multicolumn{2}{|r|}{ Step 5} \\
\hline \multicolumn{2}{|l|}{ ATTACHING MAP CONCEPT } \\
\hline $\begin{array}{l}\text { Teacher: Based on the story, the teacher } \\
\text { shared images and asks the students to } \\
\text { paste an image on a map concept that } \\
\text { has been made based on the story. }\end{array}$ & $\begin{array}{l}\text { students: } \\
\text { Pasting pictures on the map } \\
\text { a concept that has been made according to the } \\
\text { direction of teachers. }\end{array}$ \\
\hline Backa & \\
\hline \multicolumn{2}{|c|}{ Step 6} \\
\hline \multicolumn{2}{|l|}{ FORMATION GROUP } \\
\hline $\begin{array}{l}\text { Teacher: } \\
\text { Divide the students into groups based on } \\
\text { the characters in the story. }\end{array}$ & $\begin{array}{l}\text { students: } \\
\text { Establish a working group based on the } \\
\text { characters in the story, }\end{array}$ \\
\hline \multicolumn{2}{|c|}{ Step 7} \\
\hline \multicolumn{2}{|l|}{ GROUP DISCUSSION } \\
\hline $\begin{array}{l}\text { Teacher: } \\
\text { Guide students to discuss and provide } \\
\text { worksheets to each group and answer } \\
\text { them in their own language. }\end{array}$ & $\begin{array}{l}\text { students: } \\
\text { Group discussion and answer questions in a } \\
\text { worksheet using their own language. }\end{array}$ \\
\hline \multicolumn{2}{|r|}{ Step 8} \\
\hline \multicolumn{2}{|l|}{ PRESENTATION } \\
\hline $\begin{array}{l}\text { Teacher: } \\
\text { After guiding the students in the group, } \\
\text { the teacher asks the students to explain } \\
\text { group discussion results to the class. }\end{array}$ & $\begin{array}{l}\text { students: } \\
\text { Preparing presentation materials and } \\
\text { Percentage implement part of the map concept } \\
\text { had done. }\end{array}$ \\
\hline
\end{tabular}




\begin{tabular}{|l|l|}
\hline \multicolumn{2}{|c|}{ Step 9 } \\
\hline CLOSING & $\begin{array}{l}\text { students: } \\
\text { Teacher: }\end{array}$ \\
$\begin{array}{l}\text { Provide reinforcement, initial activity, } \\
\text { and guide students to conclude the } \\
\text { implementation of learning that has the discussion of learning activities } \\
\text { and always the spirit of understanding of } \\
\text { been implemented. }\end{array}$ & \\
\hline
\end{tabular}

\subsection{The importance of building the character of students in school}

Good character according to Lickona (2013) is something that we want for our children. Good character is alive with correct behavior in terms of dealing with others (such as generosity and sympathy) and relates to themselves (eg, self-control and moderation).

According to Hutcheon (1999), The most important of all the products of childhood learning is a character, and a good measure of the success of any society is how well the task of character building is being performed. This means that every learning should be integrated with the character because it is expected not just a result but also the character after carrying out activities in learning, so teachers need creative ways of presenting the characters' content learning so that students can awaken the values of a character. According to Research and Development (2010) about the values of the Culture and National Character Education comes from four main topics, namely: Religion, Pancasila, Culture, and the National Education Goals. Based on the four sources,

Latif (2009) asserts that the importance of building the spirit (character) must be accompanied by knowledge and understanding of the moral or the character itself. It is understood that the correlation of moral knowledge (moral judgment) with the actual behavior (actual conduct) in concrete situations (moral situations) is true that knowledge and moral understanding is a prerequisite for the emergence of moral action.

According to Lickona (2013) to implement character education in learning in school by using a comprehensive approach, teachers should not have to pay attention to the following points:

1) Acting as caretaker, exemplary, and counselors who treat students with feelings of love and respect, give good examples, support the pro-social behavior, and correct the erroneous actions.

2) Creating a moral community in the classroom, help students get to know each other, respect, and care and make them feel like valued members in the group/class.

3) Practicing the moral discipline, creating and enforcing rules and regulations to make it as an opportunity to foster moral reasoning, self-control, and the same respectful attitude towards anyone.

4) Create a classroom environment that is democratic, involving students in decisionmaking and share responsibility.

5) Teach values through the curriculum 
6) Using cooperative learning to learning attitudes and skills of mutual assistance and cooperation in children.

7) Building the "conscience of the work" by encouraging the growth of academic responsibility and respect for the values of students in learning and work.

8) Encourage moral reflection through reading, writing, discussion, decision, debate, and practical exercises

9) Learn conflict resolution so that students have the capacity and commitment to fair finished non-violent conflict

10) Encouraging awareness up out of the classroom

11) Creating a positive moral culture in schools

12) Invites parents and community partners in the educational value

\section{Conclusion}

Based on the study above, we can see the theoretical flow of storytelling literacy movement by using a circuit model of learning in order to improve students' character development we can draw the conclusion that literacy through storytelling can be an alternative that can be applied to the strengthening of the development of character. Literacy storytelling is a very interesting way for students because basically every child is very fond of storytelling and of this storytelling literacy students can find a code that can emulate and will apply them in everyday life. In addition, the hobby will read nonfiction or fiction began to increase from the previous.

With the craze will read and listen to fairy tales heard the students became active in communicating with his friends. In addition, the use of circuit models of learning makes the students really take the information in the same pattern. Type of circuit model of learning is cooperative learning that maximizes the empowerment of thoughts and feelings with the addition pattern (adding) and repetition (repetition) ".

\section{References}

[1] Abdul Aziz Abdul Majid. 2001. Educating the story. Bandung: Youth Rosdakarya

[2] Agelli Genlot, Annika. 2013. Improving literacy skills learning through reading by write. The method is presented and tested iWTR journal homepage. It 98104

[3] Alwasilah, C. 2009. Qualitative Principal Basics Designing and Conducting Qualitative Research. Jakarta: Pustaka Jaya

[4] Binkley, M., et al. (2012). "Defining Twenty-First Century Skills" in the Assessment and Teaching of 21 st Century Skills. New York: Springer.

[5] Boehnert, Joanna. (2013). Ecological Literacy in Design Education: A Foundation for Sustainable Design. London: DRS // Cumulus 2013 2nd International Conference for Design Education Researchers Oslo, 14-17 May 2013.

[6] Burns, A. 1999. Collaborative Action Research for English Language Teachers. United Kingdom: Cambridge University Press.

[7] Capra, F. 2002. Sustuinable Living, Ecololical Literacy, and The Birth of Life. 
Canadian Journal of Evironmental Eduvation, No. 12 pp 9-18.

[8] Carrier, SJ, 2009. The Effects of Outdoor Science Lessons with Preservice Elementary School Teachers Students on Self-Efficacy. Journal of Elementary Science Education.

[9] Cohen, L., Manion, L. \& Marrison. 2007. Research in Education Sixth Edition. Newyork: Routledge.

[10] Creswell, J. 2015. Educational Research Planning, Implementation, and Evaluation of Qualitative and Quantitative Research (Fifth Edition). Yogyakarta: Student Library.

[11] Hurlock. (1980). Child Development, Vol 2. Jakarta: PT. Primary Literacy surge.

[12] Elkabumaini, N. \& Ruhyana, R. (2016). Budi Character Education Implementation Guide For elementary, junior high school. Bandung: Yrama Widya.

[13] Kama. AH 2008. Values. Value Press. duo

[14] Kemendikbud. (2014) Technical Transition Guide SBC Into Primary School Curriculum 2013. Jakarta: Ministry of Education and Culture Directorate General of Primary Education.

[15] Kesuma, et al. (2012). Character Education: Theory and Practice Assessment in Schools. Bandung: Teen Rosda paper.

[16] Lestyarini, Beniati. 2012, Excitement Growth To Strengthen Character Nationality Indonesia Through Language Learning. Journal of Education. It 340-345

[17] Musfiroh, Radkiroatun. 2008. Stories for Early Childhood. Yogyakarta. Tiara Discourse.

[18] Oktavianti, Ika. 2017. Creation Story Book Ipa The Integrating Content Natural Disaster To Improve Literacy Reading And Character Formation. It 35-42

[19] The Government of the Republic of Indonesia. 2010. The National Policy on the Development of National Character Year 2010-2025.

[20] Reed and Tony. 2009. My Pedagogical Creed. New York: Griftin, Ltd.

[21] Soedjatmoko. 2009. Being an Educated Nation. Jakarta: Book Publishers Compass.

[22] Sugiyo. (2011). Kids Character Development through Conservation Moral Since Early, Indonesian Journal of Conservation. Volume 1 No. 1. 40-48.

[23] Utama Faizah, Goddess, et al. 2016. Free Movement Literacy in Elementary School. Directorate General of Primary and Secondary Education of the Ministry of Education and Culture. Jakarta: Secretariat of the Directorate General of Primary and Secondary Education

[24] Revelation. (2011). Problems and National Character Building Enterprises. Journal Community. Volume 3 No. 2. 138-149.

[25] Wiedarti, Prince, et al. 2016. Design School Parent Literacy Movement. Directorate General of Primary and Secondary Education of the Ministry of 
Education and Culture. Jakarta: Secretariat of the Directorate General of Primary and Secondary Education

[26] Xie, Guoyong \& Fengzhi Zhang. 2011. "A Brief Talk on the Cultivation and Improvement of Moral Education Teacher 's Quality". Asian Social Science, 7, 1.www.proquest.umi.pqd / web

[27] Zuchdi, Darmiyati, et al. 2009. Character Education: Grand Design and Values Target. Yogyakarta: UNY Press. 